\title{
Avelar Brotero, ou a ideologia sob as Arcadas
}

Miguel Reale

(Catedrático de Filosolia do Direito)

\section{O primeiro professor da Academia}

O provimento das cátedras nas recem-fundadas Faculdades de Direito de São Paulo e de Olinda deve ter constituído delicado problema para o Govêrno Imperial, logo no primeiro lustro de nossa Independência.

Ir buscar dirètamente em Coimbra mestres consagrados seria impossivel, dada a situação política, mas, ainda que possível, de todo indesejável, em virtude dos propósitos de emancipação cultural que haviam norteado os instituidores dos cursos jurídicos no Brasil.

O certo é que a 6 de Outubro de 1826, quando ainda transitava pela Câmara e pelo Senado o projeto da lei que só viria a ter vigência a 11 de Agôsto de 1827, o Imperador, atendendo ao que lhe representara o doutor José Maria DE Avelar Brotero, houve por bem "fazer-lhe mercê de uma das cadeiras do curso jurídico", que em tempo oportuno lhe seria designada.

Quem era o mestre contemplado com uma das cátedras, sem a designação siquer da disciplina ou da Faculdade em que deveria lecionar? Avelar Brotero havia chegado ao Rio de Janeiro há menos de um ano, e até então não desempenhara qualquer função universitária, nem publicado qualquer trabalho que justificasse aquêle ato de tão rara e honrosa confiança.

Bacharel em Direito pela Universidade de Coimbra em 1819, exercera o cargo de Juís de Fora de Celorico da Beira, de Março de 1822 a Junho de 1823, quando o advento da 
contra-revolução o induzira a deixar Portugal, abrigandose nos Açores, "para fugir à intriga, escreveu êle que havia contra aquêles, que tinham sido empregados no tempo da Constituição" (1).

Após pouco mais de dois anos de advocacia nas ilhas, onde se casara com Da. Ana Dabney, filha do côsul norteamericano, Avelar Brotero chegou ao Brasil aos vinte e sete anos de idade. Dir-se-á mais tarde que fôra convidado a lecionar nos projetados cursos jurídicos, mas é bem pouco provável, não só porque o Conselheiro não teria silenciado sôbre particular de tamanha monta, dado como era a registrar em um "Livro mestre" os acontecimentos principais de sua existência, como também por ter dito, mais de uma vez, que havia pessoalmente solicitado "o emprego de tanto traballio e melindre". (2)

$\mathrm{Na}$ realidade, Avelar Brotero, de formação liberal, pertencente a uma família ilustre (seu pai foi o Brigadeiro Manoel Ignácio de Avelar Brotero, comandante da Ordem de São Bento de Aviz; e seu tio avô, o Padre Felix da Sil-va e Avelar, um dos mais eminentes botânicos da época), graças não só à sua erudição e eloquência, mas também ao bafejo do Dr. Mamede, seu tio materno e médico do Paço Imperial, soube conquistar a amizade de alguns mentores políticos da época, a ponto de receber a incumbência de "vir abrir a Academia de São Paulo" por ordem de sua Majestade Imperial e determinação pessoal do Ministro Araujo Lima.

(1) Cf. as suas "Notas" autobiográficas, coligidas em Traços Biográficos do Conselheiro José Maria de Avelar Brotero, por seu neto Frederico de Barros Brotero, São Paulo, 1933, pág. 71 e segs.

(2) Sôbre o convite que teria sido feito a Avelar Brotero pelo então Ministro dos Negócios Estrangeiros, o Marquês de Inhambupe, não há senão a referência constante no Parecer do Senado, quando de sua jubilição. Fez-se, então, menção a uma estranha memória impressa na cidade de São Paulo em 1841, oferecida ao Ministro da Rússia. . (Cf. Frederico de Barros Brotero, op. cit. págs. 46 e 76). 
O seu gesto, abandonando Portugal por não suportar as imposições da reação anti-liberal, representava, sem dúvida, penhor de fidelidade ao regime constitucional recéminstaurado na novel Nação americana.

Tornava-se, dêsse modo, primeiro lente da Faculdade de Direito de São Paulo, acumulando as funções de secretário com proverbial exação, durante quarenta e três anos. Designado por decreto de 12 de Outulbro de 1827 para reger a cadeira de Direito Natural, do $10^{\circ}$ ano, proferiu a aula inaugural dos Cursos Jurídicos a $10^{\circ}$ de Março de 1828, e daí por deante timbrou em ser o mais rigoroso cumpridor dos deveres do magistério, até jubilar-se aos 22 de Novembro de 1871, tendo adquirido a cidadania brasileira um lustro após a sua fixação em São Paulo, em Junho de 1833.

Já no fim do primeiro ano letivo, conforme declara em suas suscintas notas autobriográficas, recebia ordem do Imperador para enviar o compêndio ao Rio, afim de ser impresso. Mandavam os regulamentos da época que cada lente elegesse ou redigisse um "compêndio" para o curso, e Avelar Brotero, sempre meticuloso e apaixonado, não adiou essa tarefa, dando exemplo nem sempre seguido no futuro, pois já Teixeira de Freitas se referia irônicamente a certos lentes que nada escrevem, verdadeiros "Papinianos de ciência guardada" .

Para a consecussão de seus objetivos editoriais, o nosso Avelar Brotero pôde contar com o interêsșe e o zêlo de José Clemente Pereira, Ministro dos Negócios do Império, como o revelam as cartas que lhe dirigiu. Pela leitura dêsses documentos firma-se a convicção de que Avelar BroTERo queria justificar a sua presença na Academia, insistindo na publicação do compêndio, da qual resultaria, a

(3) “pessîas que passam por Papinianos, mas de ciência guardada, só atestada por discipulos que adoram seu mestre e juram em suas palavras". TeIXeIRA de Freitas - Nova apostila sôbre o Projeto do Códígo Civil Português, Rio, 1859, pág. 215. O peor é quando nem siquer existe o testemunho favorável dos alunos... 
seu ver, "glória à Nação, pois seus ilustres representantes não deixarão passar as doutrinas contrárias ao bem ser público"; e glória ao Ministro, "fazendo calar aquêles que dizem que V. Excia. o aprovou sòmente pelas relações de intima amizade de patrícios" (sic) - e utilidade também. para o autor, "por se acabarem questões loucas". (4) Que a pressa, no entanto, não impedisse o exame do trabalho pelo ilustre Ministro, cuja "perspicaz e eruditíssima sentença" reclamava, notadamente, sôbre "aquela parte do compêndio (Cap. $4 .^{\circ}$, sôbre os "direitos do homem"), cuja doutrina é melindrosa e fêz alguma novidade entre amigos e inimigos". .

Tinha, pois, o Conselheiro plena consciência de que o seu livro não seguia à risca as linhas tradicionais dos escritos de Direito Natural; receava escandalizar amigos e inimigos, mas era necessário vir a público para demonstrar que não recebera uma cátedra por mero favor pessoal, pondo-se têrmo "às questões loucas", a que se refere na carta ao Ministro.

Em outra missiva ao Ministro, pleiteando a gratuidade da impressão, não se referira, porém, às aspirações puramente culturais da obra, mas proclamara tê-la redigido "ùnicamente" para ter com que "sustentar a família", pedindo desculpas pela "sinceridade de um estrangeiro que julga ser a franqueza uma virtude". (6)

Foi com tais cuidados e espectativas que o jovem mestre aguardou o aparecimento de seu compêndio, escrito às pressas, sob a pressão das reclamações ministeriais, encaminhando os capítulos à Tipografia Imperial, na medida em que eram elaborados como notas de aulas, que outra pretensão não tinha positivamente o seu Autor.

(4) Carta transcrita no "livro-mestre" do Conselheiro, com letra de sua espôsa. Op. cit. pág. 53.

(5) Carta de $10^{\circ}$ de janeiro de 1829, Op. cit. pág. 47.

(6) Carta à pág. 46 dos Traços Biográficos, cit. 
A triste sorte do compêndio e a história de um ressentimento.

$\mathrm{O}$ interêsse que os anunciados Princípios de Direito Natural despertaram no acanhado meio cultural paulista comprova-se com o fato de elevar-se a nada menos de 490 o número de assinantes da obra, cuja lista Avelar Brotero pedia ficasse dela constatado. Com rara solicitude governamental, atendia-se, outrossim, aos trabalhos editoriais, na Tipografia Imperial, pois já em 1829, vinha a lume o Compêndio, embora por conta do autor, que, sempre atento ao aspecto prático das cousas, soube encontrar quem lhe abonasse tôda a despesa.

Consoante assinalado, a obra foi redigida de afogadilho, sem a unidade sistemática que exige meditação e experiência. Aliás, o A. mesmo reconheceu essa irremediável deficiência de seu escrito, ao inserir, já em meio do trabalho, uma "Advertência" precedida desta nota significativa: "mais vale tarde que nunca". Era, no entanto, ainda de confiança o tom geral do livro, no qual Avelar Brotero deixou sinais de sua personalidade complexa e contraditória, ora austera e rude, ora tocada de ingênuo lirismo, como o revelado no último capítulo, ao of erecer-nos uma explicação bucólica sôbre a origem da civilização. Nem faltam no trabalho descaidas para o grotesco, de que é exemplo esta advertência aos leitores: "Se a vossa censura é filha da maledicência e capricho, sois uns entes nulos do Universo; se ela porém é filha do amor à verdade, então sois homens benfazejos e imitais ao Creador". (pág. 3).

Prevenia Brotero alguns dos inevitáveis reparos que seriam opostos a seu compêndio, primeiro quanto ao número excessivo de notas, quase tôdas em francês, tão extensas como o texto; depois, quanto à maneira um poucc insólita de tratar de certos problemas conexos com o Direito Natural, ao arrepio da tradição. Com referência a êste ponto, escudava-se êle nos "Estatutos" redigidos pelo 
Visconde dA CACHoeira e mandados adotar pela Lei de $\mathbf{1 1}$ de Agôsto de 1827, que definitivamente instituiu os cursos jurídicos no Brasil, Estatutos que, em seu Cap. 3 , $\S 3 .^{\circ}$, dispunham: "convém considerar tôdas as relacões dos homens, não em abstrato, nem como entes separados, e dispersos, mas como Cidadãos que já vivem em sociedade". Justificava, assim, o A. as suas preocupações por problemas concretos, pelas conquistas da Filosofia e das ciências naturais, o que melhor apreciaremos a seguir, para vermos se, com isso, logrou êle o propósito de "tirar ao Direito Natural aquêle seco, que parece ter à primeira vista".

Os Estatutos do Visconde dA CACHoEIra, inspirados, em parte, nos da Universidade de Coimbra de 1772, distinguiram-se por sua preocupação eminentemente prática, achegada à realidade quotidiana da advocacia e do fôro, infensos aos "longos e profundos estudos de direito romano e antiguidades", maximé quando os mestres, seguindo a escola humanista de CuJácio, "filosofavam muito teòricamente sôbre os princípios do direito, e, por fugirem o rumo de Bartolo, Alciato e mais glosadores, e casuistas, ensinavam jurisprudência mais polêmica do que apropriada à prática da ciência de advogar e de julgar". (8)

O Conselheiro Luiz José de CarvalHo e Melo não compreendia, como se vê, o estudo do Direito senão em têrmos de utilidade prática, preferindo o ensino em breves e claras explicações, sem a erudição nascida da vaidade, afim de poder esgotar-se o Compêndio em cada ano letivo. É uma orientação que ainda hoje encontra defensores, tudo

(7) Avelar Brotero - Princípio de Direito Natural, Rio de Janeiro, Tipografia Imperial e Nacional, 1829, pág. 285. Para comodidade de leitura, passaremos a indicar no texto, entre parêntesis, as remissões às páginas desta obra.

(8) Apud SPENcer VAMpré - Memórias para a História da Ácademia de São Paulo, Livraria Acadêmica, São Paulo, 1924, Vol. f, pág. 35. 
dependendo sempre da compreensão prévia do que seja uma Universidade, vista por alguns como centro de aprendizado profissional, por outros como foco irradiador de pesquisa científica, quando devera ser concebida como unidade plurivalente de formação humanística, técnica e cientifica.

Mas voltemos à orientação dos Princípios de Direito Natural que Brotero julgava poder legitimar à luz de preceito estatuário. Nada mais contrário à recomendada parcimônia de erudição do que o seu trabalho, no qual se transcrevem páginas e páginas de autores, com esta justificação suscinta: "E não bastava apontar as mesmas notas? De certo, se fôsse possível obrigar aos estudantes a ter os. autores citados. E por que vêm elas em francês? Para poupar trabalho, ou para melhor dizer, por falta de tempo. $O$ leitor deve saber que estas lições eram prontas à noite para servir de manhã, e que estas notas eram parte, ou fundamento da explicação que fiz na aula" (pag. 285).

Se o jovem mestre esperava críticas dessa natureza, estava por certo bem longe de prever o dilúvio de insultos de que seria alvo o seu trabalho.

Surgiu o ataque violento e descomedido na Câmara dos Deputados pela palavra de Lino CovtinHo, o mesmo representante que, dando provas do mais extremado reacionarismo cultural sustentara competir à Assembléia a aprovação dos compêndios: "Só o Corpo Legislativo é que deve designar as doutrinas e o método de as ensinar . Senhores, os Lentes são como as amas de leite; tôda a ama de leite diz que o seu leite é bom; mas quem é que decide? E a ama? Não, é o médico. Da mesma forma a Assembléia é que há de julgar da escolha dos compêndios". (9)

Quando coube à Câmara manifestar-se sôbre o livro do mestre de São Paulo, Lino Coutinho, que já considerara "Heinecio, na sua Ética, um verdadeiro charlatão", não poupou adjetivos rudes para ilustrar a sua crítica, na qual

(9) Cf. SPEncer VAmpré - op. cit., I, pág. 24. 
a paixão extravasa e prepondera. Não é demais transcrever as acusações que influiram decisivamente na condenação do compêndio, conservando os solecismos característicos da linguagem descuidada do primeiro Império e que os Anais da Câmara talvez tenham agravado:

"Foi offerecido aqui á camara um compendio de direito natural, feito por um lente dessa escola de direito, compendio este que é vergonha das vergonhas pelas suas imbecilidades, e mesmo compendio prejudicial pelas más doutrinas que nelle se encerrão, e que não sei como o Sr. ex-ministro do império sem examinar este compendio, sem cousa nenhuma, mandasse ou decretasse que se ensinasse á mocidade brasileira por tão infame compendio, este compendio foi offerecido á camara, e se dis recebido com especial agrado, isto apparecendo nas nações estrangeiras é vergonha para a camara dos deputados e para o Brazil inteiro pelas imbecilidades que contém, eu apontarei uma: n'um artigo em que este compendio trata da existência de Deos, diz que é um ponto duvidoso para muitos grandes espiritos, e para muitos grandes philosophos; ora, isto n'um compendio para se ensinar direitos? E então a definição do homem? Faz rir, um cathecismo que aqui appareceu, que era um cathecismo de asneiras, não sei se trazia tantas imbecilidades no artigo homem; entretanto o nosso exministro do imperio, que punio tanto pela instrução publica, como aqui se disse, mandou que se ensinasse nas escolas de direito por este cathecismo que parece ser feito por um homem tresloucado; não sei se o Sr. ex-ministro do imperio o leu; mas se o leu, muito máo conceito fico fazendo do Sr. ex-ministro do imperio e de seus talentos. Requeiro portanto que o compendio seja remettido a uma comissão"

(10)

(10) Anais da Câmara dos Deputados, 1830, Sessão de 8 de Junho de 1830, pág. 357. Grifamos as passagens mais reveladoras, a nosso ver, das razões determinantes da cólera de LiNo Coúrinfo e da condenação da Câmara. 
Ante essa crítica impiedosa, Clemente Pereira, o exministro do Império que tanto se empenhara com Brotero para a publicação da obra, preferiu retrair-se de qualquer responsabilidade escusando-se: "Eu queria que Sr. deputado dissesse quem foi que disse que eu mandei se ensinasse por êste compêndio". Deixava, assim, o ex-Ministro o livro entregue à sua própria sorte, e o veredicto da Comissão da Instrução Pública veio inexorável, em Julho de 1830:

“A Comissão de Instrução Pública examinou o compêndio de direito natural, composto e oferecido a esta augusta Câmara pelo lente do primeiro ano Jurídico de São Paulo, e, observando que não tem ligação e harmonia nas matérias, nem uniformidade no estilo, sendo uma verdadeira compilação de diferentes autores, que não seguiram os mesmos principios, nem se exprimiram no mesmo estilo; que os raciocínios não têm fôrça de convicção, nem os termos clareza e precisão; que compreende matérias heterogêneas ao direito natural, e notas repetidas e mui extensas; 'é, portanto, de parecer que não seja admitido no curso jurídico, devendo-se ensinar o direito natural por outro compêndio que melhor desempenhe a matéria".

Pode-se bem imaginar o que êsse golpe representou para Avelar Brotero. De natural já ríspido e agressivo, convencido no fundo de sua superioridade intelectual sôbre

(11) Cif. Spenicer Vampré, op. cit., pág. 95. Essa teria sido, em resumo, “a opinião dos contemporâneos", segundo pondera Clovis Bevilaqua (História da Faculdade de Direito de Recife Rio, 1927, pág. 43). Lembra o nosso preclaro civilista que o compêndio de A. Brotero não foi aceito pela Congregação de Olinda, em Junho de 1829, pois, "não lhe sendo todo presente, não podia fazer juizo certo sôbre a doutrina e sistema do autor" e também porque, estando as aulas muito adeantadas, os estudantes se iam remediando com o Fortuna (ibidem). O compêndio de Alvares Fortuna, de Jure naturae positiones delucidiore stylo et ordine, publicado em 1815, era uma adaptação, com algum desenvolvimento da abra de Martini, discipulo de WolfF, na esteira, portanto, do fusnaturalismo racionalista e abstrato. 
o meio que o acolhera, deve ter recebido o anátema legislativo com sombranceiro desdém, carregando por sua longa vida universitária a silenciosa amargura de ressentimento, dêsse complexo passional que sugeriu a Gregorio Marañon páginas tão subtis e comóventes.

Desnecessário é aquí relembrar como certas atitudes, certas manifestações psíquicas exteriorizadas, só se compreendem em função de recalques profundos, da atuação no subconsciente de um foco perturbador da personalidade. Como acentua Marañon, é dificil definir a paixão do ressentimento. Uma agressão dos outros homens, ou simplesmente da vida, aquilo que convencionamos denominar "má sorte", pode, às vêzes, ficar aprisionada no fundo da consciência, talvez inadvertida: aí incuba e fermenta a sua acritude; infiltra-se em todo o nosso ser e acaba sendo a fôrça diretora de nossa conduta e de nossas menores reações.

Em geral, continua o escritor espanhol, o homem ressentido é dotado de inteligência, embora não excessiva, pois o pobre de espírito aceita a adversidade sem êste tipo de amarga reação, a qual coincide muitas vêzes com a timidez e pode brotar de um malogro social, esvaziando a alma de impulsos de justiça e de generosidade. (12)

Não se conhece uma palavra sequer de reação por parte de Brotero; não declinou êle da cátedra conferida, nem cuidou o Govêrno Imperial de considerá-lo inepto para o exercício de tão altas funções. Tudo continuou como dantes, uma vez operada a substituição do malsinado compêndio por outro, o de Perreau, Élements de législation naturelle, livro inclor, que resumia, em estilo ampoloso, os ensinamentos superficiais de Burlamaqu, por quem o escritor francês devotava entusiasmo incondicional a ponto de escrever: "Nous terminerons cette notice par rendre hommage à l'auteur que le premier a su mettre à profit

(12) G. Marañon - Tiberio, historia de un resentimiento 2. ${ }^{a}$ edição, Buenos Aires, 1942, págs. 25 e segs. 
ce qu'il y a de bon dans tous les systèmes de jurisprudence naturelle que nous venons de parcourir, pour en composer un qui est tout à la fois le plus clair et le plus complet que nous ayons". (13)

Durante mais de quatro décadas o livro de Perreau, catecismo modelar sôbre a média das opiniões vigentes, constituiu leitura obrigatória de nossos estudantes de direito, até ao ponto de justificar-se uma reimpressão da obra em 1834, em Paris com esta nota no frontespício: “Ouvrage adopté par les Cours Juridiques de Saint Paul et d'Olinda, au Brésil”.. O século XIX avançava com os seus problemas prementes, entrechocavam-se escolas, reviam-se pressupostos, estremeciam-se convicções antigas ao impacto do criticismo, do positivismo, do evolucionismo, e o anacrônico compêndio de Perreau, com suas "verdades" desacompanhadas de inquietações e de dúvidas, permanecia no altar de nosso oficialismo cultural, como se tudo estivesse de antemão aceito e resolvido no mundo da Filosofia.

Aceitando o repudio de seu compêndio, Brotero parece ter perdido o tom jovial e confiante que animara o seu escrito: - trancou-se na vida da Academia, enclausurado nos seus misteres quotidianos de secretário e de lente com proverbial rigidês. Tudo parecia ter retornado a seu curso normal e tranquilo, mas que transformação, que mudança não se operara no homem!

O escritor, que no compêndio escandalizara a Câmara dos Deputados por pregar a tolerância até para com os

(13) Cs. PERREAu - Elements de législation naturelle destinée à l'usage des Éleves de l'école centrale du Pantheon, Paris, 1798.

(14) É preciso notar, porém, que não era só no Brasil ou em Portugal que se verificava o fato da sobrevivência dos compêndios anacrônicos. Lembra-nos AmRens, no prefácio da 1.a edição de seu conhecido Cours de droit naturel, aparecido em 1837, que há quase cem anos se estudava Filosofia Juridica na França segundo o tratado de Burlamaqui, da antiga escola de Wolff, "antiquado no fundo e na forma". 
ateus, dizendo que, se "alguns sábios talentos e engenhos raros" com suas teorias mais fruto do capricho e da vaidade do que de convicção íntima, têm negado a existência de Deus, "não têm feito mal algum à verdade da existência de Deus" (págs. 8 e 9), — o lente que afrontava, assim, a mentalidade reinante, não recusando aos ateus talento e sabedoria, consolidara suas tendências de homem intolerante e ríspido, em perene conflito com superiores, colegas e subordinados. (15)

Quem no Compêndio (págs. 170 e segs.) sustentara, contra a doutrina então dominante na cultura lusiada, ser o casamento um contrato e uma sociedade assentes sôbre o mútuo consentimento; quem justificava o divórcio como a única solução moral compatível com a necessidade da mútua compreensão que deve existir entre os cônjuges (16); quem proclamara uma perfeita igualdade entre os

(15) V. em Almeida Noguerra - Tradições e Reminiscências, São Paulo, 1907, 2.a série, págs. 9 e segs. e Spencer Vampre $O b$. cit., vol. I, págs. 86 e segs., a lamentável história das turras de Brotero com o primeiro diretor da Faculdade de Direito, o general Arouche PEndon que implorava a S. M. Imperial the concedesse demissão do cargo, pois com 73. anos, já não se sentia com fôrças para "poder aturar e sofrer a um homem, que, se não é mais alguma coisa, é de certo um louco capaz de atacar moinhos." Igualmente violentos foram seus atritos com o Prof. Veiga Cabral, assim como com funcionários subalternos. Implicava-se com um bedel porque amava a música e conciliava as suas funções humildes tocando oficlide numa banda local; com outro porque gostava de ler jornais nos intervalos de aula.

E claro que o repudio do Compêndio não é bastante para explicar tais repentes, mas não é đde se excluir tenha contribuido para a explosão de tendências que a formação iluminística e liberal até certo ponto refreava.

(16) "O Compêndio, - escreve BRotero, personalizando grotescamente o seu livro, - estabelece como regra que o divórcio só pode ter lugar, ou quando faltar o consentimento mútuo ou quando faltar a aptidão para a propagação. De que serviria, com efeito, a união do homem com a mulher quando faltasse o mútuo consentimento?" Op cit. pág. 187. 
esposos, por conservarem êstes na sociedade conjugal a igualdade de direitos existente no ato da convenção (pág. 184 e segs.); quem reclamara o uso cordial e benígno da autoridade paterna, apesar de reconhecer o poder absoluto dos pais sôbre os filhos para os fins de educação e de seu esclarecimento racional (págs. 191 e segs.) volve aos rudes e severos costumes da família portuguêsa, exagerando-os ao extremo, convertido em marido tirânico e em pai de autoridade incontrastável. Sua casa tornou-se um verdadeiro cláustro, onde, no meio do carinho dos filhos e dos escravos irrequietos, $\mathrm{D}^{\mathrm{a}}$. Ana Dabney, graças à sua ilustração e à delicadeza de seu espírito, ainda conseguia fazer reinar uma atmosf era de confiança e amizade. (17)

O admirador de Mably, de Holbach, de Helvetius e de Cabanis, que desafiara os princípios de uma sociedade baseada no trabalho servil, repetindo o ensinamento daquele abade socialista-revolucionário, de que "tôda alma grande e generosa olha para a escravidão como o maior de todos os males", pois "o nome de senhor e de escravo destrói tôda a idéia de dever, todo o comércio de afeição e põe os homens em um estado de hostilidade recíproca, e neste mísero estado a fôrça é o direito, e o medo a única obrigação" (pág. 216), - palavras que tanto condenavam a sujeição política como a do negro escravizado, - tornouse um escravocrata insensivel. No seu "Livro Mestre", onde anotara encomendas de obras de Locke, de Martens ou de PAley, lembra secamente o prejuizo na venda de um escravo: "Mulato Joaquim que custou $564 \$ 120$ foi vendido por $419 \$ 560$ — perdi $141 \$ 560 . "$

(17) V. as cartas deveras comovedoras da esposa do Conselheiro Ввотеко, batendo sempre na mesma tecla: "Infelizmente vivo tão retirada que não sei nada do que vai fora de casa"; "Sinto não seber noticias de fora para te contar, mas sabes como nós vivemos"; "Tu bem sabes dos costumes claustrais da casa.."; "Deus sabe como êle (o genro, Dr. Nicolau Queiroz) se tem sujeitado a nossos costumes monásticos.." (Frederico de BARRos BRotero - Traços biográficos, cit. págs. 6 e segs.) 
Nas aulas, porém, em contacto com a juventude, é bem possivel que, olvidados os insonsos ensinamentos de PERREAU, voltasse aos seus pendores juvenís, pregando idéias capazes de provocar os entusiásticos aplausos dos acadêmicos, consoante a tradição unânime registra. A preleção nos moldes oratórios então em voga, era um escape, uma válvula de expansão para o mestre ressentido, que talvez, no fundo, se regozijasse com o reconhecimento de seus méritos, vendo de certa forma reparada a afronta pública recebida. Daí esquecer êle, o mais apaixonado e rigorista seguidor dos Estatutos acadêmicos, a proibição de aplausos em classe, para esclamar emocionado:

— "Mas, quem é que pode dominar a emoção? Ora, aplaudam, meus m'ninos, aplaudam quanto quizerem, ao velho mestre!"

Em dois pontos conservou, porém, nítida a sua formação de iluminista e de ideólogo, jamais falhando em sua fidelidade ao constitucionalismo liberal e aos preceitos da mais ampla tolerância religiosa.

\section{Julgamentos de Almeida Nogueira e de Spencer Vampré}

Em linhas gerais, o juizo dominante sôbre a personalidade de Avelar Brotero consiste em considerá-lo um homem ríspido e excêntrico, mais notável pela sua dedicação funcional do que por méritos de inteligência e de cultura, sendo apontados os Princ ${ }^{a}$ pios de Direito Natural como uma aventura malograda nos domínios da Filosofia social e jurídica, em parte compensada com a obra posterior sôbre prêsas maritimas, mais consentânea com os seus pendores de jurista positivo. (18)

(18) Cs. Avelar Brotero - Questões sôbre iprêsas marítimas, da qual se tiraram duas edições, uma em 1836 e a outra em 1863, esta com acréscimos. Além dêste livro e dos Princípios, mais dois foram com segurança, por têle publicados: Princípios de Direito 
Na tradição, porém, o que mais sobreleva não é nem mesmo a dimensão do mestre dedicado ou do estudioso das leis positivas, mas antes o homem com as suas implicâncias e cacoetes, com o seu vício de inverter sílabas e confundir palavras, nos arroubos da eloquência que todos, "una voce", lhe atribuem.

Repetem-se ainda hoje as "broteradas", as confusões grotestas como aquela, de difícil crédito, de uma ordem dada ao bedel Mendonça para apagar as garatujas da parede na iminência da visita imperial: "Sr. Imperador, Sr. Imperador, apague essas mendoncinhas que o garatuja aí vem".

Essas e outras anedotas incorporaram-se à história da Academia, e os seus memorialistas exímios, Almeida Nogueira e Spencer VAmprÉ acolheram-nas com finura e discrição, "com a devida e respeitosa cortezia", reconhe-

Universal, folheto de 80 páginas, aparecido anônimo em 1837, conforme declaração do autor em seu "Livro Mestre" (Cis. Traços Biográficos, cit. pág. 75) e mais um drama politico intitulado Tumulto do Povo em Évora, de 102 págs., publicado também em São Paulo. Por outro lado, Brotero não chegou a publicar os anunciados Principios históricos compilados para servir de preliminares ao Compêndio de Direito Natural e Direito Público. É possivel que só tenha existido apostilas. Sacramento Blake, em seu Dicionário Bibliográfico Brasileiro alude a mais dois trabalhos: Filosofia do direito constitucional, São Paulo, 1868, 166 págs., e os três primeiros parágrafos de VATELL - Direito das gentes. Liv. 1, cap. I, Principios de Direito Público Universal ou Filosofia do Direito Constitucional, dividido em 20 lições. Creio que esta última obra não seja senão o folheto de 80 páginas acima referido, que também é anônimo, abrangendo número idı̂ntico de páginas e de lições. Há na biblioteca da Faculdade um exemplar com a dedicatória de Avelar Brotero de próprio punho, com êstes dizeres: "Oferecido à Biblioteca pelo A." O título dessa edição de 1842 já é diverso: "Filosofia do Direito Constitucional, embora no sub-título se encontrem as referências a VATELl. Terá havido nova edição dessa obra, ampliada para 166 páginas, em 1868, como afirma Sacramento Blake? o que não pude averiguar. 
cendo quanto a fantasia pode ter bordado sôbre o fundo irrecusável da verdade. (19)

O que nos atrai, todavia, na personalidade de Brotero, não são as atitudes do ranzinza impenitente ou do orador que baralhava sílabas e frases, mas sim a significação histórica, mais do que o valor intrinseco de sua obra filosófica-jurídica, inclusive para compreender-se melhor a sua presença na cátedra de Direito Natural durante quase meio século.

Almeida Nogueira, após lembrar que, acordes todos os documentos da época, era o Dr. Avelar Brotero mais do que eloquente, eloquentíssimo, não pôde examinar os Princípios de Direito Natural, mas aventou, com admirável prudência, a hipótese de exagero na condenação da Cầmara dos Deputados.

"Não me foi possível, escreveu o saudoso lente de Economia Política, por falta de elementos, apreciar a justiça dêsse julgamento, pois têm sido vãos até ao presente os esforços por nós empregados para conhecer c texto dêsse trabalho".

"Quer-nos parecer, todavia, que para tão rigorosa condenação muito contribuiu o atrazo mental da época, em contraste com o espírito adiantado que o Dr. Brotero sempre revelou".

Já o mestre SPEncer VAMpré pôde proceder a um estudo mais acurado da obra de BRotero, concluindo por dar razão ao pronunciamento da Câmara, não sem atribuir as deficiências do trabalho "ao açodamento com que se houve, esquecido de que a pressa é inimiga da perfeição".

Segundo VAMpré, o nosso A. parece não ter sido em nada influenciado pelas lições com que vinham revolucionando a Filosofia Jurídica pensadores franceses, inglêses e alemães da segunda metade do século XVIII e do começo do século dezenove:

(19) V. Almeida Nogueira, ob. cit., 1.a série, págs. 30 e 2.a série págs. 14 e segs. SPEncer Vampré, ob. cit. Vol. I, págs. 89 e segs. 
"O Espírito das Leis, de Montesquieu, que alargou os horizontes do direito, merece, apenas, uma ou outra fugitiva alusão, sem que tenha, de qualquer modo, enriquecido a mentalidade de Brotero.

"Kant, já conhecido e vulgarizado em São Paulo, (sic) por José Bonifácıo e Manoel Joaquim do Amaral Gurgel, não lhe merece sequer ligeira referência, não obstante a sua aspiração de constituir-se o Copérnico do mundo moral.

"Não falemo sem WolfF, em LeibNiz, nem nos inglêses Burke, Hume e Bentham.

“ $O$ Dr. Brotero, se não era alheio aos escritos dêstes precursores da moderna filosofia do direito, tão apressado andou no redigir o seu compêndio, que o melhor se lhe escapou das mãos.

"Não admira, pois, que, tendo-o remetído à Assembléia Legislativa, fôsse lá recebido a ponta de lanças." (20)

Apreciando o valor intrínseco dos Principios de Direito Natural assim se pronuncia o nosso antigo catedrático de Direito Romano:

"O Compêndio, como o chamava o autor, foi carregado de excessivas anotações, - algumas em latim e em português, - porém, a maior parte, em francês, e extraídas da obra de Mably, Droits et Devoirs des Citoyens.

"Além de Mably, que é o seu escritor predileto, repontam, aquí e alí, trechos de Helverius, de Perreau, de $\mathrm{C}_{\mathrm{A}}$ Banis, de Barthez, e de outros somenos, mas tudo sem critica e sem método.

"O próprio autor sentia, aliás, êsses defeitos." (21)

Daí a conclusão de que a Brotero "escasseava, sobretudo, o espírito crítico, a penetração aguda que extrema

(20) VAMPRÉ — op. cit., vol. I pág. 94. São vários os autores. que se referem à participação de José Bonifácıo e de Martim FranCISco na difusão da doutrina de KANT, mas é assunto que merecemaiores esclarecimentos. V. a nossa A Doutrina de Kant no Brasil, São Paulo, 1953.

(21) VAMPrÉ — vol. cit. pág. 92. 
pontos aparentemente próximos, mas, na realidade, inconciliáveis, e oferece os materiais para as sínteses filosóficas".

Embora não possamos discordar dessa análise, quanto à carência de espírito crítico na apreciação de certas doutrinas, pensamos que é mister situar melhor a obra de Brotero no mundo das idéias de seu tempo, para mostrar que não era um espírito alheio às influências contemporâneas, como se afirma.

Sob muitos aspectos, estave êle "à la page" com as correntes de pensamento de sua época, tendo desempanhado um papel deveras interessante para quem se empenha no estudo desapaixonado de nosso desenvolvimento mental.

\section{Avelar Brotero e os pensadores de seu tempo}

Em seus preciosos Subsídios para uma História da Filosofia do Direito em Portugal (21) Cabral DE Moncada pondera que, duma maneira geral, pode dizer-se "que foram particularmente as idéias do Locke e Condillac as que maior influência exerceram sôbre o sensualismo português, na sua feição moderada, não metafísica mas positivista, que lhes permitiu combinarem-se sem grande dificuldade com o espiritualismo escolástico e o racionalismo leibnitziano e Wolfiano. Não deve confundir-se o sensualismo, que é, como dizem, uma doutrina psico-genética das idéias, com o materialismo, que é uma doutrina metafísica, embora a primeira tenha muitas vêzes sido o melhor caminho que conduz à segunda. Das duas correntes derivadas do sensualismo de Condillac, uma materialista (representada por Lametrrie, Diderot, Cabanis etc.) e outra espiritualista, representada sobretudo por BonNEr, só esta segunda penetrou em Portugal". (23)

(22) - 2.a Edição, Coimbra, 1938, pág. 17, nota.
$(23)$ - Loc. cit. 
Ora, considerando-se a obra de Avelar Brotero integrada em nossa literatura, ou se quizerem, na bibliografia filosófica luso-brasileira, representa ela, em nosso meio, exatamente a influência do sensualismo que vem de CoNdillac a Cabanis, passando por Helvetius e Holbach. O que poderíamos denominar "sensualismo de esquerda", talvez sem grande impropriedade, encontra no primeiro mestre de nossa Faculdade um reflexo digno de maior exame.

Não é que Ávelar Brotero haja assumido uma posição materialista, por êle repudiada em mais de uma passagem, mas no seu livro os autores que procura conciliar, paradoxalmente, com as suas concepções de espiritualista católico tolerante, são os que CABRAL DE Moncada declara não terem penetrado em Portugal.

Não é MarLy, a nosso ver, o escritor que mais vincada influência exerce sôbre o espírito do Conselheiro. Essa influência, apontada, como vimos, por SPEncER VAMpré; opera-se apenas em certos planos de Filosofia Moral e Política, naquela parte da doutrina de MABLy de caráter menos revolucionário. Às idéias coletivistas do ABBÉ MABLy, à sua pregação sôbre a propriedade e a desigualdade das fortunas como fonte real de todos os males sociais, ou seja, no que se refere pròpriamente à sua Filosofia Social, mantém-se alheio o autor dos Principios de Direito Natural. (24)

Os escritos com os quais mais se conforma a mentalidade do Conselheiro são, no entanto, os do HoLbach, Helvetius e Cabanis, escoimados de elementos materialis-

(24) BRoteno revela conhecer e admirar tôdas as obras funmentais 'do abade frances. Não é só de Droits et devoirs du citoyen, que êle extrai longos trechos para as suas notas abundantes, mas também dos Entretiens de Phocion, De la Législature ou du Principe des Lois, De l'étude de l'histoire, etc. Não é demais lembrar que, em 1791, aparecera, na Tip. Nunesiana de Lisboa, uma tradução portuguêsa das Instruções de Phocion a Aristias, o que demonstra a forte repercussão dessas idéias na pátria de Brotero. 
tas ou anti-religiosos. Pelo cotejo que pudemos fazer de alguns trechos, verificamos o cuidado com que Brotero transcreveu as afirmações daqueles autores, afastando de sí qualquer suspeita de adesão às suas pregações materialistas ou anti-clericais.

O cuidado de Brotero vai ao extremo de não citar uma vez siquer, o nome do barão Von HoLbach, embora lhe cite as duas obras principais, A Moral Universal e Sistema da Natureza, delas estraindo páginas e páginas que conserva em francês nas notas, chegando mesmo a traduzir-lhe todo um capítulo, para adotá-lo em seus Princípios de Direito Natural. (25)

O mesmo receio que levara Holbach a editar sob pseudônimo, em 1770, o seu Système de la Nature, ou les Lois du Monde physique et du Monde Moral, - destinado a transformar-se para muitos, no dizer de F. A. LANGE, no código ou bíblia do materialismo (26) - ainda induz BRotero, em 1828, a conservar o anonimato das obras holbachianas que cita.

A má fama do palavroso e enfadonho barão germânico, com o seu ateismo e anti-clericalismo declarados, aconselhavam talvez a silenciar um nome por si só capaz de suscitar violenta reação. E vimos que tal prudência de nada valeu ao nosso autor, fulminado pelo veredictum da Câmara.

$\mathrm{O}$ propósito de conciliar as doutrinas do racionalismo tradicional com as teses do sensualismo de Condillac e de

(25) Dentre as várias transcrições de trechos de Holbach, sobresaem, nãc só, por sua extensão, mas tamb́ćm por seu significado, as 8 páginas dedicadas aos "devoirs des ministres de la religion" (Cf. Princípios, págs. 340-47); as 4 páginas sôbre o prazer e a dôr (ob. citada, págs. 366 e segs.), as dedicadas aos deveres de humanidade (págs. 431 e segs.) ou ao amor e ao desejo (págs. 172 e segs.).

(26) LANGE — The history of materialism, 3.a ed., Londres, 1950, pág. 93. 
seus epígonos "materialistas" revela-se logo no capitulo inicial do livro que estamos analisando, ao dar o conceito de "natureza". Fazendo remissão à pág. 8 do "Sistema da Natureza" de Holbach, cujo nome, como já disse, silencia, mas com expressa e contrastante invocação de Helverius, escreve êle: "Natureza é um têrmo que se usa tomar em diferentes acepções, umas vêzes significa o mundo, a máquina do Universo, ou a reunião de todos os entes criados, ou, como diz Helvecio, o grande todo que resulta da reunião das diferentes matérias, das suas diferentes combinações e diferentes movimentos". (pág. 5).

Tudo é, portanto, "natureza, resultante da reunião das infinitas combinações da matéria e de seus diversos movimentos"; mas, entendamo-nos, Brotero procura esquivar-se inteiramente do panteísmo ou do materialismo, recorrendo à distinção entre "natureza naturante" e "natureza naturata", conferindo àquela todos os atributos que o espiritualismo tradicional liga à idéia de Deus, criador do Universo, onisciente, eterno, infinito etc.

A distinção entre natura naturans e natura naturata, formulada pela primeira vez por Averroes para designar a Deus como ser total e unitário perante todos os seres criados, adquiriu densidade de significado a partir da época renascentista, notadamente na obra de Giondano Bruno $e$ de Nicolau DE Cusas, para, afinal, atingir, no sistema de Espinosa, a plenitude de sua acepção panteista, entendido por "natura naturans" o que é em si e por si, a Substância infinita, unidade vivificadora e compreensiva de "natura naturata", concebível esta como todos os modos dos atributos de Deus.

Antes, porém, de se integrar a doutrina nos sistemas panteistas, tivera ela foros de cidadania na Escolástica medieval, apresentando-se Deus como "natura naturans", em contraposição à "natura naturata", conjunto dos seres e das leis por êle criados. Ranzoli lembra, a propósito, os ensinamentos de VICENTE DE BEAuvais: "Natura dicitur 
dupliciter; uno modo natura naturans, id est ipsa summa naturae lex quae Deus est, aliter vero natura naturata". (27)

Não faltavam, por outro lado, autores do século XVIII e do princípio do XIX que conservassem a apontada distinção, depurada de intenções panteístas, o que explica tenha o jovem mestre luso se sentido à vontade para adotá-la, empregando, assim, uma terminologia que, pelo menos exteriormente, aparentava uma conciliação entre concepções irreconciliáveis.

Quem se der ao trabalho de estudar os Principios de Direito Natural, poderá verificar que a sua nota dominante, da primeira à última página, é a de manter-se fora de suspeitas de heresia ou de heterodoxia, mas sem prejuízo da inabalável convicção do autor quanto à necessidade de se propagarem as verdades do sensualismo de Condrllac e de seus continuadores até Cabanis e Destutr de Tracy, verdades que, escoimadas de exageros, lhe pareciam plenamente harmonizáveis com um espiritualismo aberto e tolerante.

Longe de nós a idéia de atribuir a Brotero a concepção de uma doutrina superadora das antíteses e dos antagonismos tão pronunciados existentes entre os sensualistas e os seus adversários das escolas racionalistas, cartesianas ou escolásticas. Na realidade, o nosso A. limita-se a justapôr doutrinas, deixando muitas vêzes em suspenso o leitor que, no cipoal de suas citaçôes, pretenda vislumbrar a clareira de seu julgamento. Dai a dificuldade de atingirlhe a unidade e a coerência das convicções.

Abstração feita, porém, dêsse ecletismo empírico, e o ecletismo tem sido uma espécie de refúgio para muitos pensadores de Portugal, um dos povos menos metafísicos do Ocidente, - será interessante verificar quais as princi-

(27) Cf. RANzoLI - Dizionario di scienze filosofiche, 5.a ed., Milão, 1952, “natura”. 
pais teses da Filosofia sensualista acolhidas pelo Compêndio.

Se indagarmos, inicialmente, das fontes inspiradoras do sensualismo de Brotero, será possível talvez encontrá-las nos ensinamentos de dois ilustres mestres de Coimbra, Rodrigues de Brito (pai) e Silvestre Pinheiro Ferreira.

$O$ primeiro foi professor de leis na tradicional Faculdade Iusa, tendo publicado, em 1803, as suas Memórias Políticás, que o situam, no dizer de Cabral de Moncada, como "um sensualista e um empirista da escola de Locke e Condillac, na sua feição não materialista como Cabanis e Broussais, mas mais psicologista, como Villers e DegeRANDo", assumindo concretamente uma atitude hedonista em Moral e utilitarista quanto aos problemas sociais, nos moldes do economismo fisiocrático. (28)

Maior deve ter sido, porém, a influência recebida de Silvestre Pinheiro Ferreira, um dos mais eminentes pensadores e juristas de Portugal no século passado. Antes de ausentar-se de sua terra natal, - e longe dela viveu quase quarenta e seis anos, legando-nos copiosa bibliografia em português e em francês, como o seu notável Cours de droit public, editado em Paris, em 1838, - Pinheiro Ferreira lecionara no Colégio das Artes de Coimbra, até 1793, compondo, nessa época, as suas Prelecões filosóficas, depois editadas no Brasil, em 1813, na Imprensa Régia. (29)

O ministro constitucional de D. João VI era, como em geral os pensadores lusos, um espírito atraído pelas cousas práticas e positivas, avesso à expeculação metafísica, pre-

(28) Cabral de Moncada - ob. cit., págs. 27 e segs.

(29) Cs. na Biblioteca Nacional êsse precioso trabalho para a história do pensamento português, Preleções Philosophicası sobre a Theoria do Discurso e da linguagem, a esthetica, a diceosyna $e$ a cosmologid.

Notável para a época foi a atividade da Imprensa Régia, que, entre outras obras de cultura geral, já nos dera, em 1812, uma tradução de escritos de Burke feita pelo Visconde de Cayrú, sob o título 
servado "do tenebroso borbarismo dos Heráclitos da Alemanha e da brilhante fantasmagoria dos de França", por preferir "a Filosofia do senso comum dos homens, exposta na linguagem singela da raça humana". (30)

Adversário declarado de Kant, de Schelling, de Fichte e do "famoso Hegel", insusceptíveis, a seu ver, de compreensão e até_mesmo incompreendidos uns dos outros, ao ponto de repudiarem duas e três vezes os sistemas que haviam ensinado como chefes de escolas, Pinheiro FerReira, além de a Aristóteles, só tece lôas a BAcon, Leibniz, LOCKE e CondiLlaC, os "quatro ilustres modernos", a quem jamais um adversário pôde "taxar de icompreensíveis".

Na realidade, porém, como observa com razão CÁBral DE Moncada, fazia êle metafísica a seu modo, mantendo-se inconsequentemente metafísico.

Avellar Brotero, como se vê, formara a sua cultura em um meio já fortemente impregnado das idéias de Locke e de Condillac, nas quais os moços encontravam um motivo de renovação espiritual, de luta contra a tradição escolástica. Daí a nascer a admiração pelos filósofos materialistas, de menor valor intrínseco mas de maior sentido revolucio-

EDMUNDo BURK - Extratos das obras politicas e econômicas, Tradeduzidas de inglês por José DA SILvA LISBOA, parte I.

Quanto ao pensamento de Prineiro Ferreira, vide, além de suas obras jurídicas, as suas Nocões elementares de Philosophia geral e aplicada às sciencias moraes e politicas, Paris, 1839. Nesta obra, referindo-se ao utilitarismo moral de Helvetius, de Holbach e de Bentham, escreve Pinheiria Ferreira: "Posto que nós não aprovemos muitas das doutrinas dêstes escritores, não podemos deixar de fazer-lhes a justica de reconhecer que, não só não ensinaram que o útil do torpe egoismo pudesse jamais ser o móvel das nossas ações licitas, mas, em muitos lugares de seus escritos, recomendam se entenda que só falam daquele útil que compreende tôdas as pessôas interessadas, o que se reduz ao princípio do justo: o maior bem possivel de todos em geral e de cada um em particular” (pág. 96). Brotero, como veremos é de igual opinião.

(30) Pinheiro Ferreira - Noções elementares de Filosofia, cit. pág. VI. 
nário, foi questão de oportunidade ou mesmo fruto das agitações politicas em que se viu envolvido.

$\mathrm{O}$ certo é que, ao redigir as suas aulas, a sua personalidade de escritor quase que se biparte entre fôrças contrárias, e, as vêzes, temos a estranha impressão de estarmos lendo dois livros justapostos: no texto, repontam doutrinas tradicionais, com a sua fraseologia anacrônica e convencional; e, ao pé das páginas, as transcrições dos autores prediletos, ressumando, apesar de tôdas as suas falhas, um espírito novo, tocado pelas preocupações das ciências naturais e da problemática complexa do homem no limiar do século XIX. (31)

\section{Sensismo e ideologia}

Nenhuma dúyida sôbre a adesão de Brotero à tese fundamental do sensismo quanto à gênese das idéias: “o

(31) A critica de inatualidade feita por VAMPRÉ a Brotero não me parece procedente, por todos os motivos já expostos. Se é exato que êle não demonstra conhecer KANT (citado mais tarde, em sua Filosofia do Direito Constitucional $\S 10^{\circ}$, por conceber o Direito Natural como "a metafísica do Direito"), se não seguia Burke e outros, não se pode dizer que se mantivesse preso à velha tradição dos estudos do Direito Natural. São menos expressivas as suas referências a autores da Escola de WolfF, a Martinli, a Fortuna, a Felice ou mesmo a Perreau. Em contraposição, revela-se um entusiasta das obras de Destutt de Tracy, de Cabanis, e de Bichat, expoentes do pensamento francês daquele tempo, além das de Frlangieri, BlasksTONE, MABLY, sem se falar na já apontada admiração por Condrllac, Helvetius e Holbach. Além disso, demonstrava acentuado interêsse pelos estudos de Fisiologia, de Química e de História, invocando, em várias passagens, os ensinamentos de BufFolN, BARTHEZ, BLUMENBACH, Addison etc. Situado como estava na corrente sensista, pode dizerse que não desconhecia a linha de seus mais recentes desenvolvimentos, tais como os dos "ideologos", dos quais logo mais me ocuparei. $\mathrm{O}$ que se pode criticar em Brotero é a falta de assimilação efetiva idas doutrinas que põe em cotejo, sem perceber os valores próprios, mas não a falta de curiosidade e de atenção pelas idéias de seu tempo. 
homem, assevera o nosso autor, recebe, bem como os brutos, das impressões dos sentidos a matéria prima de suas idéias, dos seus juizos, de suas afeições, e estas impressões exercem sôbre o mesmo homem um império muito poderoso". (pág. 58) Invocando uma passagem de Cabanis, que dá como definitivamente assente ser a sensibilidade física a fonte de tôdas as idéias e de todos os hábitos, acrescenta: "A primeira faculdade, que nós vemos no homem, e da qual todos: os nossos conhecimentos dependem, é o pensar; e a base essencial do pensar é o sentir". (pág. 136)

Émbora julgue que "pensar e sentir são sinônimos", não vai até o ponto de aceitar o reducionismo sensista de Condillac até à sensação táctil como base de tôda a vida pesíquica. Se "pensar" e "sentir" são sinônimos, é porque está presente em seu espírito a lição de Desturt DE Tracy em seus Éléments d'idéologie: "La faculté de penser ou d'avoir des perceptions renferme donc les quatre facultés élementaires appelées la sensibilité proprement dite, la mémoire, le jugement et la volonté". (pág. 148)

Brotero tocava, dêsse modo, em uma questão capital para distinguir-se o sensismo de Condillac do de Destutr de Tracy, o maior representante da "Ideologia", daquela corrente de idéias que, marcando uma sobrevivência das concepções do Enciclopedismo iluminista no início do século XIX, representava, por outro lado, um traço de união entre a Filosofia do Século XVIII e o positivismo. (32)

Consoante é observado por BREHIER, o reducionismo sensista de Condillac, na explicação da gênese das idéias,

(32) Nesse sentido, v. Brenier - Histoire de la Philosophie, t. II, Paris, págs. 600 e 604. Não é menos certo, como observa NicolA Aebagnanio, que do seio mesmo da ideologia ressurgia o espiritualismo tradicional (Storia della Filosofia, Turim, 1950, vol. II, Parte II, pág. 198). Aliás, a obra póstuma de CaBanir., Carta sôbre as causas primeiras sustentando uma Metafísica espiritualista, revela a projeção ambivalente da corrente "ideólogica", servindo de ponte de passagem para o positivismo e o espiritualismo. 
é criticado por Destute de Tracy, para quem há quatro faculdades primitivas e independentes, acima apontadas (sensibilidade "stricto sensu", memória, entendimento e vontade).

BRotero percebe a divergência das idéias, mas, levado por sua tendência conciliatória, não compreende a necessidade de optar, preferindo sugerir uma combinação: “ $O$ leitor, escreve êle, deve consultar o autor supra citado (de Tracy) e combinar (sic) sua doutrina com aquela da Lógica de Mr. Condillac. (33)

A leitura dos ideólogos, especialmente de Cabanis e de DestutT De Tracy, parece ter influenciado o nosso estudioso de Direito Natural a não ver o homem originàriamente como "a estátua de Condillac, porque, diz êle, "outras causas, que não são as sensações, podem determinar em nós o exercício dos movimentos de vida animal" (pag. 124). A seu ver, "julgamos pelas impressões recebidas em outro tempo, pelas que recebemos atualmente, ou pelas que nós mesmos criamos. A memória, a percepção e a imaginação

(33) Principios, cit., pág. 149, nota. O Sr. J. Cruz Costa, no entanto, adeanta que sòmente em 1854, por obra de Ferreira França, "apareciam no Brasil as idéias de DestutT DE Tracy".. ("Revista de História", n. 19 - pág. 182). Nesse ponto, a prioridade cabe indiscutivelmente, a BRoTERo, que já em 1829 se referia ao mentor da Ideologia, acolhendo alguns de seus ensinamentos. Cr. Principios, págs. $26,146,148,150,371,375,401$ etc. Na realidade, as idéias de Tracy lograram certa repercussão no Brasil logo nas primeiras décadas do século passado, a ponto de ser traduzida uma de suas obras Memórias sôbre quais os meios de fundar a moral de um povo, em 1837, pelo Prof. Lopes Gama, diretor da Faculdade de Direito de Olinda. Cs. Glovis Bevilaqua — op. cit. pág. 114.

Por outro lado, é preciso esclarecer que Ferreira França, quando publicou em 1854, as suas Investigações de Psicologia já não era mais "imbuido das idéias da escola chamada sensualista, entusiasta de Destutr de Tracy"; mas as havia abandonado pelo espiritualismo de MAINE DE BIRAN, que "contribuira especialmente para esclarecer a sua inteligência". (Nesse sentido, v. Silvio RoMERo - A Filosofia no Brasil Porto Alegre, 1878, págs. 14 e segs.) 
são as bases principais, sôbre que apoiam tôdas as operações do entendimento, e em suma estas bases repousam mesmo sôbre a ação dos sentidos". (34).

Situa-se Avelar Brotero, como nos parece provado, na linha do sensismo revisto por Cabanis e por Tracy, quanto à origem das idéias, sendo também em vários outros pontos un seguidor da "ideologia", embora com tôdas as vacilações e contradições que comprometem a sua obra.

Referimo-nos, especialmente, ao seu entusiasmo pelas ciências naturais, notadamente pela Fisiologia, anunciando tôda uma orientação que iria lograr predomínio absoluto entre os pensadores brasileiros algumas décadas depois, na fase do positivismo e do evolucionismo. $\quad$ deveras sintomática essa inclinação de Brotero pelos dados de experiência, tomados empiricamente como a base de todo o universo moral.

Vale a pena transcrever alguns trechos de suas lôas à Fisiologia, com a qual sumàriamente identifica tôda a Ciência do Homem, reclamando a atenção dos jurisconsultos pelos problemas do ser humano como entidade fisiológica, pelos que denomina, genéricamente, "princípios de matéria médica".

Nada mais absurdo, a seu ver, do que o desconhecimento "dos princípios anatômicos da construção humana", das leis explicativas da vida, entendida esta, consoante a lição de Bıchat, como "a união das funções que resistem à morte". (pág. 180 e segs. notas 3 e 10).

"Que triste Jurisconsulto há de ser aquêle que, principiando a conhecer a marcha da Jurisprudência se enfas-

(34) Loc. cit. E pos'sivel comparar-se essa teoria das impressões atuais e das passadas com a que DE TrAcy correlaciona às faculdades fundamentais. Na realidade, como nota AbBagnano, não. há, quanto à gênese das idéias, diferença radical entre os sensistas do sec. XVIII e os ideólogos, os quais apenas não reduzem a vida psiquica à sensação total primordial, e atribuem a origem da idéia do mundo exterior ao "movimento" que nos faz esbarrar em obstáculos externos. 
tia de conhecer a natureza do ente para quem a Jurisprudência é destinada! Os princípios de Direito Natural, base essencial da Legislação, jamais podem ser apreendidos com aproveitamento e utilidade sem que primeiro se tenha uma leve noção do que é o animal homem.

"Não é o Direito Natural o mesmo ditâme da razão concernente às ações humanas? São as ações humanas tôdas iguais? São as modificações do homem filhas do acaso, ou são filhas das suas necessidades e das suas paixões?"

" $E$ como há de o Jurisconsulto saber a razão das diferenças estabelecidas primitivamente na natureza do homem, sem que indague primeiro da sua organização? Como há de conhecer os princípios da razão, e da Moral, sem que primeiro conheça as bases invariáveis da formação das idéias; e como conhecer estas bases sem primeiro ter uma noção da construção do corpo humano, da razão, da variedade das sensações, e da influência que as circunstâncias físicas têm sôbre elas?"

"Como nos pode a razão ditar normas para procurarmos o bem ser do nosso próximo, quando a mesma razão ignora o que é a natureza humana, e como esta se pode aperfeiçoar? Como pode o Chefe de familia educar a prole sem que conheça a vida orgânica, e a vida animal, e as alterações que estas sofrem pela mesma educação? Como poderá o Legislador aperfeiçoar os usos e costumes de uma Nação, sem saber as necessidades reais, do homem, sem saber a razão por que a dôr e o prazer são o móvel da ação humana; sem conhecer a razão da ignorância dos povos, e sem conhecer os meios de fìsicamente remediar êste mal? Como poderá tal Legislador decretar contra as paixões do homem, quando não conhece a origem das mesmas? E como acautelar estas paixões, quando êle ignora a natureza e a fôrça do hábito, e quando depende o moral do físico? Como poderá o Juiz pensar a moralidade da ação sem conhecer a natureza do ente que a praticou, e a influência 
que as circunstâncias físicas podiam ter sôbre a mesma natureza?" (ob. cit.; pag. 114. Nossos os grifos).

Eis ai uma série de exigências estranhas ao Jusnaturalismo da velha escolha de WolfF e de Burlamaqui, antecipando a preocupação positiva pelos problemas biológicos e a subordinação das questões morais ao prévio estudo das condições mesológicas, climáticas e sobretudo fisiológicas. Na linha dessas idéias, Brotero mostra comungar com CABANIS no propósito de fazer da Fisiologia, lato senso, a base de tôda a Filosofia: "Mais c'est peu que la physique de l'homme fournisse les bases de la philosophie rationelle; il faut qu'elle fournisse encore celles de la morale: la saine raison ne peut les chercher ailleurs". (pág. 116 nota).

\section{A vocação iluminista}

A tese central de Cabanis sôbre a subordinação das atividades psíquicas às corpóreas ẻ das mais claramente aceitas por Avelar Brotero, que insiste sôbre a importância dêsses estudos para o jurista, à página 139 e seguintes de seu Compêndio, pois, a "ciência física humana", escreve êle, "tem fornecido armas para o bem e para o mal, e o verdadeiro meio de evitar o mal é fazer desaparecer o monopólio dela, monopólio de que se têm servido os tiranos para triunfar da liberdade dos povos; os impostores para fundar suas seitas; os Legisladores para regular as ações de Nações bárbaras, e tirar as mesmas do seu estado feroz, e do pélago das paixões sem freio; e os verdadeiros moralistas para esmagar a superstição e fazer triunfar a virtude."

Nota-se, neste passo, a tensão do homem ainda embebido de preocupações iluministas, do homem do século XVIII, formada sob os influxos da era pombalina, confiante nos poderes da razão esclarecida, e que, no delbar da nova centúria juIga encontrar, como os ideólogos, uma alavanca de progresso e de civilização na "ciência do homem". 
No fundo, o fisiologismo de ideólogos como Cabanis não representava senão o desenvolvimento de umạ das tendências marcantes do "século das luzes". Na sua análise penetrante do Aufklörung, ERnSt CASSIRER aponta também a aspiração iluminista de decifrar o ser da natureza graças ao conhecimento do ser do homem: "A fisiologia do homem converte-se em ponto de partida e chave do conhecimento da natureza. A matemática e a física matemática são deslocadas do lugar central que ocupavam, substituidas, entre os fundadores da doutrina materialista, pela biologia e a fisiologia geral. LAMETTRIE parte de observacões médicas; d'HolbaCH apoia-se sobretudo na química e nas ciências da vida orgânica. DIDERoT objeta à filosofia de Condillac que não basta se ater à simples sensação como protoelemento do real". (35).

É essa tendência que Brotero conserva e desenvolve, atualizando-a com os mais recentes ensinamentos de $\mathrm{CA}_{\mathrm{A}}$ BANIS e de Bichat, mas refugindo sempre das conclusões materialistas dos autores de $O$ Homem máquina ou de $O$ Sistema da Natureza.

Apesar de seus pendores pelo que denomina "ciência médica", Brotero continua sendo, como se vê, um entusiasta da Ilustração, crendo que "o gênero humano nasce com aptidão de razão, porém não nasce com a razão esclarecida" (ap. 191). Não é de somenos lembrar que, em pontos fundamentais, apega-se êle às idéias de Holbach e de FilanGIERI, de quem traduz algumas páginas. Do iluminista italiano recebe a doutrina sôbre a origem das instituições políticas, afastando-se do contratualismo de Rousseau (págs. 164 usque 170). De acôrdo com Filangieri, não admite que o homem possa ter vivido originàriamente fora da sociedade, mas distingue entre o "estado primevo" ou "sociedada puramente natural", sem classes e sem leis, e a "sociedade civil", nascida esta em virtude da renúncia da liber-

(35) CASSIER - Filosofia de la Ilustracion, trad. de E. IMAZ, México, 1943, pág. 75 
dade natural" para a conquista da liberdade garantida pelo Estado.

Expressiva da formação iluminista é especialmente a sua irrestrita tolerância religiosa, com afirmações dêste jaez: "Já nós vimos que a Religião é um vínculo necessário para a felicidade do homem, e que ela deve ser praticada com ampla consciência, isto é, com plena liberdade; já vimos também que, não existindo esta plena liberdade, pode sim existir o culto corpóreo, porém nunca o culto moral, faltando desta maneira a essência da Religião." (pg. 226).

A seu ver, o fanatismo ou a intolerância fazem "destruir a marcha física e a ordem da natureza, fazem destruir a marcha moral, que deve existir na espécie humana", tornando-se impossíveis as relações sociais, sucedendo-se o estado de guerra ao estado de paz (pág. 227).

É lícito aos homens, acrescenta, "insinuar em seus semelhantes a virtude", cumprindo-lhes "excitá-los com exemplos ao aperfeiçoamento da sua razão" e ao conhecimento da Religião revélada, "porém, ensinar não é obrigar" (pág. 228).

Católico firme em sua fé na existência de Deus, na imortalidade da alma, e nos valores morais de sua Religião, após transcrever a declaração de Helvetius sôbre "a falsidade de tôdas as Religiões, excepto a cristã", que se não confunde com o papismo, Brotero ressalva seu ponto de vista, ponderando que Helvetius "de certo confundiu o verdadeiro papismo (sic) com o fanatismo e a superstição", de maneira que seria mais certo dizer: "à excepção da Religião Católica Apostólica pura, id est sem fanatismo, sem superstição" (pg. 225, nota 1).

O Conselheiro crê, dêsse modo, no esclarecimento expontâneo e livre da razão assim como na emancipação da espécie pela cultura, visto como "o homem é o fabricador dos instrumentos, e com êstes mesmos instrumentos chega a aperfeiçoar a natureza e a si próprio". (pg. 117) 
Com apôio no material sensório, logra o ente humano realizar o que o distingue do bruto, as ciências, as artes, a indústria, o comércio, tudo o que é bom e "é a herança da vida exterior". Contrastando com a perfectibilidade do homem desenvolve-se a vida dos outros animais, "que jamais abandona os limites que a natureza lhe impôs". (pg. 125, nota).

À superioridade do homem une-se um igual direito de aperfeiçoamento e de ilustração, tendo a "Natureza naturante" formado "o entendimento humano igual em todos os homens, igual no seu estado de aptidão a ser perfeito". (pág. 76). “Os homens não são iguais no esclarecimento da sua razão, porém são iguais em procurar todos os meios para conseguir êste esclarecimento; êles não são iguais nas faculdades físicas, porém tếm todos igual direito para procurar todos os meios de melhorar e aperfeiçoar estas mesmas faculdades". (pg. 237)

Crê nas virtudes da educação, mas não segue até final os ensinamentos de HeLveruus em dois pontos essenciais : não crê ná posibilidade da reforma ilimitada do homem "ab imis fundamentis", sòmente graças às luzes crescentes da educação (36); e recusa a preponderância dos fatores externos na formação da personalidade (pg. 126, nota). Relativamente à primeira questão, prefere as reservas de Holbach opostas ao otimismo pedagógico da modelagem integral do homem. Por outro lado, repugna-lhe ver no homem mero produto da "organifłação exterior": ‘̀ teoria de Helvetius pensa poder contrapôr os ditâmes da "íntima consciência" que afirma a originalidade do dom da razão.

Conjugam-se, dêsse modo, mais uma vez, doutrinas heterogêneas, mas, não obstante o amálgama das idéias, pode-se dizer que predominam sempre opiniões próprias de um espírito inconformado e renovador.

(36) Cs. HeLvetus - De l'homme, de ses facultés intellectuellesi et de son éducation, Londres, 1776. 
No capítulo $4^{\circ}$ do compêndio, por exemplo, destinado ao estudo dos Direitos do homem, o nosso A. toma posição nìtidamente liberal, seguindo mais de perto as lições de Perreau sôbre os "quatro direitos sagrados do homem", a Liberdade, a Igualdade, a Propriedade e a Segurança, direitos de natureza tal que "não existindo um, não existem os outros" (pg. 211). Daí a oposição a ForTuna, o comentádor de Martini na Faculdade de Coimbra, que, a seu ver, chegara "ao absurdo de dizer que se pode alienar os direitos sagrados do homem". (37).

Pode haver eclipses da liberdade, mas o espírito humano, "constituíldo livre, será tal eternamente, não obstante todos os esforços que podem aparecer para lhe lançar cadeias; a ignorância o pode escurecer; os prejuizos podem fazer retroceder a liberdade; a corrupção pode fazer esfriar esta faculdade, porém nada disto pode fazer calar a voz da natureza", que nos atesta termos sido dotados por Deus de liberdade, cuja destruição importaria em violar a lei da natureza (pgs. 220 e segs.).

Defensor interemato da liberdade de pensar, e da liberdade de consciência, almeja a propagação da crença católica, mas em virtude de convicção expontânea: “A convicção religiosa é operação do espírito, escreve êle em seu estilo sempre descuidado, é operação de perceber uma ver-

(37) Evidentes são as conexões entre o pensamento de PeRREAU e o de Brotero a propósito dos direitos do homem, da união conjugal, do problema dos deveres etc., chegando a fazer, às vezes, mera adaptação do texto francês. Mesmo nessas passagens, mostra-se o nosso A. mais arrojado, tirando conclusões, em matéria de divorcio ou de liberdade de consciência, cuja fonte imediata eram Ma'bly, Holbach, Cabants, etc. (Cf. Perreau, op. cit. $1^{\mathrm{a}}$ ed. págs. 50 e segs. e Brotero, op. cit. págs. 170 e segs. e 210 e segs.). Não menos acentuada é a influência de Perreau no concernente à matéria da chamada "legislaçạ̃o natural", mas o nosso estudo limita-se a apreciar as idéias gerais que serviam de base làs iconcepções juridicas de Brotero.

Sôbre os ṕressupostos iluministas dos ".direitos inalienáveis do homem", cs. Cassirer - op. cit, pág. 238. 
dade; e, depois desta operação, o coração convencido do bem o abraça com zelo, e submete-se aos seus decretos com firmeza e constância; no ato religioso é necessário que a inteligência seja esclarecida pela razấo, e que o coração seja afetado pela persuasão, mas nem uma, nem outra cousa pode existir sem haver liberdade, logo a religião natural (sic) também não pode existir sem liberdade de consciência". (pg. 222)

Homem de idéias avançadas em relação à época e ao meio, como ponderou Almeida Nogueira, era natural que o seu livro suscitasse escândalo inclusive por defender algumas teses que ainda hoje provocam celeuma: o divórcio, por consentimento mútuo; o êrro do celibato dos padres (38) e não ser o direito de testar fundado em Direito Natural, mas em mera convenção. (39

(38) Quanto a êste ponto, v. nos Principios a págs. 394 e segs. o capitulo intitulado: “A castidade absoluta é contrária às leis da Natureza" Segundo o Conselheiro, quem pratica a castidade absoluta comete um crime, calca aos pés a razão, excede os limites morais de sua liberdade e se torna um simples bruto" Ao fazer tais afirmações, invocava êle o ensinamento de SÃo PaUlo: "oportet ergo episcopum unius uxoris virum esse, et diaconi sint unius uxoris viri, qui filiis suis bene praesint et suis domibus", transcrevendo três páginas veementes de Gorani (Recherche sur la science du gouvernement, vol. II, págs. 75) contra o celibato dos padres. A questão estava na ordem do dia, no acêso da discussão, desde quando a voz autorizada de padre Diogo Antonio FeiJó se erguera, em outubro de 1827, na Câmara dos Deputados, sustentando a dispensa do celibato em célebre Parecer (Demonstração da necessidade da abolição do celibato clerical) editado em folheto em 1828. Sôbre o assunto eram conhecidos os pronunciamentos favoráveis, dentre os liberais, de homens como Evaristo da Veiga e Berniardo de Vasconcelos (cf. Otávio TarQuínio de Sousa - Diogo Antônio Feijó, Rio, 1942, pág. 83) e, poucos anos depois, em 1834, apareceria a resposta do Padre AmAral Gurgel, ao Arcebispo da Bahia.

Não era, pois, isolada nem inovadora, no paiz, a opiniảo de Brotero, a qual, no entanto, se distinguia pelos seus fundamentos predominantemente "fisiológicos" com apôio em Cabanis e BuffoN.

(39) V. Principios, pag. 264 


\section{Hedonismo e utilitarismo}

As considerações expendidas já bastam para mostrar como estava influído o pensamento de ВRотеRо pelas idéias hedonistas e utilitaristas desenvolvidas na linha da Filosofia francesa que vai de Lamettrie a Cabanis.

A obra de Holbach, que provocara o soberano e justo desprezo de GOETHE, aquela coleção de superficialidades com que se comprazia a metafísica materialista, é que constitui o cerne do pensamento de Brotero no domínio de suas concepções éticas.

E sobretudo nas páginas da Morale Universelle, do palavroso barão germânico que êle vai buscar as suas teorias sôbre o amor conjugal, o interêsse, o prazer e as paixões, combinando-as com ensinamentos de Cabanis e de Bichat sôbre o instinto e o hábito. (págs. 174 e segs. e 203 e segs.).

"O homem, - escreve êle depois de várias considerações "para melhor se entender a marcha das paixões e a origem da moralidade", - o homem é sujeito à grande lei da atração, e por esta fôrça não conehcida êle sempre corre a procurar o prazer". (pág 206). Sempre batendo nessa tecla, passa a dar conselhos relativamente ao predomínio da razão sôbre as paixões, à necessidade de "desprezar as primeiras sensações das paixões animais", de "sofrer com paciência o desprezo do belo sexo", de "conhecer quão perigosa é a sua conquista", de "habituar a conhecer que com o amor não se brinca" . Bastam êstes exemplos para mostrar a que banalidade descia o nosso A., máxime quando volvia a sua atenção aos problemas do amor.

Se Holbach lhe ensinava a pôr de lado os temores e os preconceitos, que impedem o homem de seguir os impulsos da natureza física, sua guia e mestra, Brotero não via necessidade de renegar sua crença em Deus para atender ao chamado dos instintos, em razoável medida: "Se 
a Natureza Naturante não quiz que o homem tivesse apetites, para que lhe deu as mesmas necessidades físicas, e para que lhe deu a razão para alcançar estas mesmas necessidades?" Nada, pois, justifica que o homem "seja um misantropo, inimigo capital do amor, da ordem física da natureza, e da lei determinativa da mesma divindade" (pág. 366).

Tôda a teoria das paixões resumida no compêndio, a págs. 372 e segs. é inspirada em Holbach e Helvetius, com os quais concorda Brotero, temperamental por excelência, ao reconhecer que "um homem destituído de paixões e desejos é um ser inutil a si e aos outros" (40)

Pôsto entre os polos do prazer e da dôr, sob o impulso de suas paixões, o homem deve seguir os ditames da razão e da natureza, lembrando que "o fim principal de tôda a sociedade é fazer cooperar todos os seus membros para o bem comum; é portanto necessário que cada um regule sua conduta de maneira que possa alcançar êsse fim". (pág. 219).

Para isto, é mister se tenha sempre presente que "a verdadeira liberdade deve ser sempre regulada pelo conhecimento do verdadeiro interêsse" (pág. 212) Mas que é "interêsse"?

"Nada mais fácil é do que clamar contra o interêsse, e do que defendê-lo; o custoso entretanto é limitá-lo, e achar o meio têrmo nele estabelecido pelas leis da natureza" (pág. 407).

Invocando Helvetius, para quem, "se o universo físico é submetido às leis do movimento, o universo moral o ć às leis do interêsse", o nosso primeiro mestre de Direito Natural não titubeia em asseverar que "quando a nossa alma se delibera a praticar a virtude, funda-se no interêsse

(40) Compare-se com Holbach - La Morale Universelle ou les devoirs de l'homme, Paris, 1820, T. I, págs. 33 e segs.; e HeLvetius - De l'esprit, Paris, 1776, pág. 245: "De la superiorité d'esprit des gens passionés les gens sensés". 
de agradar à Natureza Naturante", e que tudo se subordina "no interêsse da suprema felicidade, do supremo gôzo, do eterno descanço" (pág. 411). E, assim, nessa imprevista simbiose, fundem-se o hedonismo e o teismo: sem interêsse não seriam possíveis a Religião, os vínculos de fraternidade e os gestos heróicos; o interêsse útil a nós e a nossos semelhantes coincide com os desígnios mesmos de Deus...

"A felicidade, já afirmára êle, consiste nos prazeres, para os quais a natureza nos destinou, e que o bom uso de nossa razão nos faz alcançar e obter" (pág. 214).

Damos aquí por terminada a tarefa que nos impusemos de proceder a uma revisão do esquecido Compêndio de Avelar Brotero, o que procuramos fazer com indispensável simpatia, mas sem preocupações restauradoras," e muito menos apologéticas.

As notas aquí coligidas talvez valham para o esclarecimento de um momento decisivo de nossa atividade cultural, em geral esquecido pelos que, na história de nossas idéias, têm-se deixado levar pelo "parti pris" de não dar a devida atenção às contribuições das Faculdades de Direito de São Paulo e de Recife, os dois focos dominantes da cultura pátria por mais de um século.

$\mathrm{E}$ se quizerem a impressão final de quem analisou com carinho a obra do Conselheiro, diremos que, apesar de seu estilo anacrônico o monótono, de suas contradiçôes manifestas, de sua falta de sistema e de organicidade, e de suas afirmações ingênuas e às vêzes grotescas, há na improvisada obra do mestre recém chegado a São Paulo, um sôpro vivo de modernidade, de arrôjo e de entusiasmo, que não mereciam as críticas acerbas ditadas pela paixão que suas idéias suscitaram. Com todos os seus inegáveis defeitos, talvez o Compêndio, condenado pelas autoridades 
públicas, tivesse sido mais benéfico, pelo fermento das idéias que provocava, do que as lições de Perreau, bem alinhadas e polidas na mediocidade e no bom senso.

Aos que considerarem êste julgamento demasiado benévolo, lembraremos as palavras encomiásticas com que Sllvestre Pinheiro Ferreira, talvez o mais culto dos portuguêses de seu tempo, acolheu a obra de Avelar Brotero, escrevendo-lhe em 1831:

"Por um discípulo de V. $\mathrm{S}^{\mathrm{a}}$. (Menezes Drummond) tive a fortuna de obter os filosóficos compêndios de Direito Natural que V. $S^{a}$. coordenou para uso de sua classe nessa Universidade. Felicitei os alunos dela de terem tão bom guia, e o Brasil de contar entre os fundadores dessa sua primeira Academia pessoa de tão abalisados talentos e tão vasta erudição". (41).

(41) Cf. Frederico de Barros Brotero - op. cit., pag. 68. 